\title{
Score for the Assessment of Body Image and Health Diagnosis Based on Anthropometric and Biochemical Measures in the Elderly
}

Anna Cláudia Freire de Araújo Patrício1, lana Virginia Bezerra Félix², Thays Domingos de Brito Rodrigues ${ }^{2}$, Brenda Feitosa Lopes Rodrigues², Ana Rebeca Soares de Medeiros², Milenna Azevedo Minhaqui Ferreira², Antônio Herculano de Araújo Neto², Maria Amanda Pereira Leite ${ }^{2}$, Richardson Augusto Rosendo da Silva ${ }^{3}$

\section{Abstract}

Objective: Identify a score for the diagnostic assessment of health and body image based on anthropometric and biochemical measures in the elderly.

Method: Transversal research exploratory and quantitative approach, developed in the South of the city of João Pessoa-PB with 21 elderly practitioners of physical exercises in sport aerobics in the period of May to June 2015. It was used a sociodemographic questionnaire and the International Physical Activity questionnaire, IPAQ. The research was authorized by the ethics on Research Committee of the University Center of João Pessoa/PB, CAAE 38840214.7.0000.5176.

Results: The study subjects had an average age of 65.9 and standard deviation 6.92 years. It was observed in table 2 the importance of body fat Mass and waist hip as the most influential in lifestyle, according to the non-parametric test of McNemar suitable for dichotomous dependent data. In table 3 the importance of all variables with exception of Edema as the most influential in body image, according to the non-parametric test of McNemar

Conclusion: It is observed that the elderly present composition of body fat mass and relative CK high, according to the measure of proximity of Jaccard, thus most of the elderly are in opposition to a healthy lifestyle. It is essential for the understanding of the characteristics and the transformations that the individuals with the advancement of age
1 Enfermeira. Doutoranda pelo Programa de Pós-Graduação em Enfermagem. Universidade Federal do Rio Grande do Norte/UFRN. João Pessoa/PB, Brasil.

2 Graduanda em enfermagem. Centro Universitário de João Pessoa/UNIPÊ. Grupo de Estudos e Pesquisa sobre Envelhecimento e Representações Sociais.

3 Enfermeiro. Professor Doutor, do Curso de Graduação e do Programa de PósGraduação em Enfermagem (Mestrado Acadêmico e Doutorado). Universidade Federal do Rio Grande do Norte/UFRN. Natal/RN, Brasil.

Contact information:

Milenna Azevedo Minhaqui Ferreira.

Address: Rodovia BR-230, KM 22, s/n. Água Fria, João Pessoa-PB, 58053-000. Tel: 83-35766736.

” milenna_minhaqui@hotmail.com 
which reinforces the need for more effective actions in the control and/or prevention of health-related factors in the elderly.

\section{Keywords}

Elderly; Body Image; Physical Activity; Quality of Life.

\section{Introduction}

The quality of life is considered to be the perception of the individual as your position in life, in the context of culture and value system, in which he lives in relation to your goals, expectations, standards and concerns [1].

Due to physiological decline during ageing existing muscle mass in humans and the force that reaches peak levels between the second and fourth decades of life suffers a drop in percentage, it is estimated that we lost about $1 / 2 \%$ of our muscle mass per year, this percentile increases between 1\% and 2\% annually after 50 years and then the 3\% annually after the age of 60 [2].

To minimize such effects, it is necessary that the individual stop being sedentary, decreasing in 40 percent the risk of death from cardiovascular disease, when linked to a proper diet and physical activities, showing a change in behavior can lead to significant improvements in health and quality of life [3].

The elderly population presents high prevalence of overweight (58.4\%) and obesity (19.4\%). The physiological process of aging causes changes in body composition resulting from the increase in body fat over lean mass, related to the decline of physical activity and decrease in basal metabolism rate [4].

The risk factors for cardiovascular diseases (FRCV) can be classified into modifiable and nonmodifiable arguments. In the first, are smoking, the hypercholesterolemia (high LDL-c), melittus diabetes, obesity (body mass index [BMI] greater than $30 \mathrm{~kg} / \mathrm{m}^{2}$ ), sedentariness, abdominal fat, a diet low in fruits and vegetables and the psychosocial stress. Among the not modifiable, are relevant to family history of premature cardiovascular disease, age (greater than 45 years male and female greater than 55 years) and sex [5].

In General, fat-free mass includes the mass of soft tissue and bone mineral content, gradually decreases during old age, along with an increase in body fat. Although BMI is widely used as a simple indicator to analyze body composition, isolated verification can mask age-related changes in fatfree mass and in lean soft tissue that occurs during aging. We can say that the loss of fat free mass is the key component of sarcopenia indicating loss of skeletal muscle mass, strength and function, leading to functional incapacity. Therefore, it is necessary to consider also the fat free mass, fat mass and skeletal muscle mass [6].

It is worth mentioning that $d$ between all these aspects the way the elderly sees and accept your body are psychological and social aspects that may influence the promotion of disability and interfere negatively in the process of active and successful aging. The old guy, the body image can be distorted, due to the different aspects that encompass from physiological changes, socio-economic changes of family structures, demands for public policy and distribution of resources in society. Due to these changes, many elderly feel marginalized and end up rejecting his own aging, by virtue of the image that are of themselves, developing feelings of selfdeprecation and low self-esteem [7].

However, the negative conception of aging, characterized by progressive decline and loss of abilities, has been deconstructed from evidence that the well-being and positive perception of this process are relevant protective factors against the effects of age on the functioning of the body [8]. 
Whereas the ageing population is a reality and brings great challenges, especially for the health sector. Seen nutrition's role in modulating the aging process, in the etiology of diseases and associated functional declines with age, the diagnostic assessment of health and body image based on anthropometric and biochemical measures of elderly are needed for adequate assistance and for planning health promotion actions, the relevance of the present study.

In this regard, studies on diagnostic assessment of health and body image based on anthropometric and biochemical measures of nutritional status appropriate to the different modalities of care are also aspects that deserve attention, especially because the central focus is to promote the identification of risk and early intervention to reduce the impact of the loss of functionality, demonstrating the relevance of the present study.

Thus, this study aimed to identify a score for the diagnostic assessment of health and body image based on anthropometric and biochemical measures in the elderly.

\section{Method}

This is an exploratory study, transversal and quantitative. Held in the city of João Pessoa/Paraíba, on the South side of that city. Were selected for the study 21 individuals, practitioners of physical exercises in sport aerobics, aged 60 years or more. As criteria for inclusion, should perform physical activity in water aerobics at least three months and not have the metallic structure in the body that prevent the measure through bioimpedance equipment octopolar InBody 720. It is worth mentioning that were considered in this study the elderly as elderly status regulated by Law 10,741/2003, those aged over 60 years, justifying the inclusion criterion [9].

The style of life, proteins, minerals, water, total body fat mass, waist, hip and edema were evaluated with use of bioimpedance octopolar InBody
720 (Biospace, Seoul, Korea), with patients in 2 to 3 hours fasting and without practicing physical exercise in the hours leading up to the test preparations defined in the literature [10]. The InBody 720 uses 8 electrodes, being 2:00 pm contact with the Palm (E1 and E3) and thumb (E2 and E4) of each hand and 2:00 pm contact with the front part (E5 and E7) and heel (E6 and E8) of each foot, allowing to evaluate 4 compartments of body mass (total body water, proteins, minerals and fat mass). Five segmental impedances (right arm, left arm, torso, right leg and left leg). Several studies documenting the accuracy of this equipment in the estimation of total and segmental body composition [11].

An instrument has been applied on body image nine original silhouettes, proposed by Stunkard scale, which represents a continuum from the thinness ( 1 silhouette) to severe obesity (9 silhouette). The elders chose the number of silhouette that they considered similar to his real body appearance and silhouette that matched their ideal body appearance. For the assessment of body satisfaction, removed themselves from the real body appearance ideal body appearance, and can range from minus 8 to 8. For variation equal to zero, the individual was classified as satisfied with their appearance and, for non-zero variance, was classified as dissatisfied. If the difference was positive, it was considered a dissatisfaction by excess weight and, when negative, a dissatisfaction by thinness.

The data observed in this research were transposed to a spreadsheet in EXCEL and then converted to a file compatible with the statistical package Statistical Package for the Social Sciences (SPSS) that has enabled the preparation of statistical analyses with the models and techniques employed for the construction and validation of the scoring. We performed a descriptive statistic, mean, standard deviation of average frequencies, proximity matrix Jaccard distance for dichotomous data. It was also the McNemar Test to evaluate the influence of variables on the lifestyle, whereas a significant $p<0.05$. 
From acceptance to participate in the study, each subject received two copies of the informed consent as established by resolution 466/12 [12] and the anthropometric measurements were collected individually. The collection occurred in the period of May to June 2015.

The study was approved by the ethics and Research Committee of the Centro Universitário de João Pessoa - UNIPÊ, CAEE/ZIP CODE: 38840214.7.0000.5176. all participants were asked to sign the informed consent (TFCC) in accordance with resolution 466/2012 National Health Council that governs the research between human beings [13].

\section{Results}

The study subjects had an average age of 65.9 and standard deviation 6.92 years. Table 1 shows the matrix of Jaccard distance proximity to the variables of the study.

You can observe the values of this array that the variables: body fat mass and waist hip are those that are less in agreement with the lifestyle. In other words, the measure of proximity of Jaccard reports that these two variables are as opposed to a normal lifestyle as well as a body image satisfaction. It is observed that the closer to 1 greater proximity between the variables, say greater affinity or fillet.

Table 2 shows the influence of the variables under the lifestyle of the study subjects.

Table 1. Array of Jaccard distance proximity to dichotomous data. João Pessoa/PB. $N=21$.

\begin{tabular}{|l|c|c|c|c|c|c|c|c|}
\hline \multirow{2}{*}{ Variables } & \multicolumn{9}{|c|}{ Array of proximity } \\
\cline { 2 - 10 } & $\begin{array}{c}\text { Body } \\
\text { image }\end{array}$ & Lifestyle & Protein & Minerals & Total Water & $\begin{array}{c}\text { Mass of g. } \\
\text { Corp. }\end{array}$ & $\begin{array}{c}\text { CQ } \\
\text { Relationship }\end{array}$ & Edema \\
\hline Body image & 1.000 & 0.438 & 0.412 & 0.333 & 0.421 & 0.125 & 0.250 & 0.313 \\
\hline Lifestyle & 0.438 & 1.000 & 0.550 & 0.750 & 0.619 & 0.067 & 0.133 & 0.647 \\
\hline Protein & 0.412 & 0.550 & 1.000 & 0.714 & 0.842 & 0.063 & 0.059 & 0.526 \\
\hline Minerals & 0.333 & 0.750 & 0.714 & 1.000 & 0.857 & 0.050 & 0.100 & 0.650 \\
\hline Total water & 0.421 & 0.619 & 0.842 & 0.857 & 1.000 & 0.053 & 0.105 & 0.600 \\
\hline Mass of Body Fat. & 0.125 & 0.067 & 0.063 & 0.050 & 0.053 & 1.000 & 0.000 & 0.077 \\
\hline CQ Relationship & 0.250 & 0.133 & 0.059 & 0.100 & 0.105 & 0.000 & 1.000 & 0.154 \\
\hline Edema & 0.313 & 0.647 & 0.526 & 0.650 & 0.600 & 0.077 & 0.154 & 1.000 \\
\hline
\end{tabular}

Table 2. Influence of variables on the lifestyle. João Pessoa/PB. $N=21$.

\begin{tabular}{|c|c|c|c|c|c|}
\hline \multirow{2}{*}{ Variables } & \multicolumn{2}{|c|}{ Lifestyle } & \multirow{2}{*}{ Risk } & \multirow{2}{*}{ IC $95 \%$} & \multirow{2}{*}{$\begin{array}{l}\text { McNemar's } \\
\text { Test }\end{array}$} \\
\hline & Freak $(n=6)$ & Normal $(n=15)$ & & & \\
\hline Protein & 5 & 11 & 0.550 & 0.048 to 6.266 & 0.999 \\
\hline Minerals & 5 & 15 & 4.000 & the 8.5451 .872 & 0.063 \\
\hline Total water & 6 & 13 & 1.462 & the 1.9841 .077 & 0.289 \\
\hline Mass of Body Fat. & 0 & 1 & 0.700 & 0.525 to 0.933 & $<0.001 *$ \\
\hline CQ Relationship & 0 & 2 & 0.684 & 0.504 to 0.929 & $<0.001$ * \\
\hline Edema & 2 & 11 & 5.500 & the 0.71042 .600 & 0.687 \\
\hline
\end{tabular}


Table 3. Influence of variables on body image. João Pessoa/PB. N = 21 .

\begin{tabular}{|c|c|c|c|c|c|}
\hline \multirow{2}{*}{ Variables } & \multicolumn{2}{|c|}{ Body image } & \multirow{2}{*}{ Risk } & \multirow{2}{*}{ IC $95 \%$} & \multirow{2}{*}{$\begin{array}{c}\text { McNemar's } \\
\text { Test }\end{array}$} \\
\hline & INSAT. $(n=13)$ & Satisfied. $(n=8)$ & & & \\
\hline Protein (N) & 9 & 7 & 3.111 & 0.281 to 34.419 & 0.021 \\
\hline Minerals (N) & 13 & 7 & 2.857 & 1.572 to 5.192 & 0.002 \\
\hline Total water (N) & 11 & 8 & 1.727 & 1.177 to 2.535 & 0.001 \\
\hline Mass of Corp. (N) & 0 & 1 & 0.350 & 0.193 to 0.636 & 0.016 \\
\hline CQ Relationship (N) & 0 & 2 & 0.316 & 0.163 to 0.612 & 0.031 \\
\hline Edema (N) & 8 & 5 & 1.042 & 0.169 to 6.402 & 0.227 \\
\hline
\end{tabular}

It can be observed in Table 2 the importance of variables, body fat Mass and waist hip as the most influential in lifestyle, according to the non-parametric test of McNemar suitable for dichotomous dependent data. A similar conclusion is obtained with the risk showing these that only these two variables the values have their confidence intervals focused on values below 1 showing that these two variables contribute significantly to a normal lifestyle.

As the influence of the variables and body image Table 3 demonstrates.

It can be observed in Table $\mathbf{3}$ the importance of all variables with exception of Edema as the most influential in body image, according to the non-parametric test of McNemar suitable for dichotomous dependent data.

The conclusion from the risk shows that only two variables body mass and waist hip have their confidence intervals focused on values below 1 showing that these two variables contribute significantly to greater dissatisfaction. Dissatisfaction is likely to be affected by more factors. However, considering the proximity matrix and the risk there is more evidence that the same variables that affect the lifestyle are also influential in satisfaction of the individual with body image.

It is concluded that there are more influenced by measures that are noticeable to the eye than those who hide in the biochemical tests before the external perception of the body.

\section{Discussion}

Body composition indicators available in table 1 to evaluate the nutritional status in the elderly, which is an indicator of health and quality of life. As results of this survey the body fat mass and waist, hip are those that are less in agreement with the lifestyle, contributing to body image dissatisfaction. However, it also can be seen in this study that these two variables are directly related to the normal/healthy lifestyle.

It is remarkable that the composition of body fat mass and waist, hip are high, which corroborates with other studies and show that this finding is important, if it is taken into account that changes in body mass composition are frequent among elderly, moreover, the excess is considered a modulation factor and has been associated with a large number of diseases [14, 15, 16].

Research conducted in Natal/RN (2009) pointed out that the waist, hip relationship in elderly showed high for those who do not practice physical activity and also revealed a significant effect of style and life in body composition, corroborating the results of this study.

Data from different countries indicate that with increasing age occur changes in anthropometric characteristics, based on endogenous and environmental phenomena, socioeconomic, lifestyle $[6,17,18]$.

The increase in the redistribution of body fat with increased accumulation in trunks, viscera, and reduction in members, is connected to major body modifications, such as a reduction in lean mass, par- 
ticularly muscle mass and bone mineral density [18]. Aging is characterized by morphological changes, especially with accumulation of body fat and lean body mass reduction, a process known as sarcopenia $[6,19]$.

The assessment of abdominal fat is linked to several metabolic changes that include dyslipidemias, insulin resistance and hypertension and morbidities such as cardiovascular disease. These can infer the need of using medicines and are of equal magnitude for both genders $[19,20]$.

It was found that the waist circumference in elderly practitioners of water aerobics is the variable most important to determine the anthropometric silhouette real, a result that in line with the recommendation of the World Health Organization indicating that measure how relevant nutritional health parameter [21].

The self-perception that the elderly has in relation to your body is important because it impacts on body image [22]. In Table 2 it is possible to infer that the variables of greater influence with regard to dissatisfaction in relation to body image are: body fat mass and the waist, hip relationship, because changes in these variables are visible to the naked eye and are usually associated with excess weight. The subject feels different not in stereotyped by society standards of beauty and may cause problems in the emotional aspect.

Study of active elderly practitioners of water aerobics picked up as well as on present research body image shows a statistically significant relationship with the abdominal circumference, and 25.8\% who were satisfied with their body image, 1.6\% dissatisfied for leanness and $72.6 \%$ dissatisfied by overweight [21].

The waist, hip relationship is an anthropometric index that indicates in simplified form, the distribution of body fat, whereas central and peripheral or abdominal fat [23].

Table 3 mentions that the study variables, except the edema interfere with body self-image that the individual features. Being the waist, hip ratio as an indicator of body satisfaction research is necessary because ta variable is combined with the presence of cardiovascular risk, related to excess weight or some other reason for the aesthetic appearance [24].

The perception of body image and the feelings of dissatisfaction which can influence negatively the General life of the people, their professional performance and even the interpersonal relationship are associated with overweight and obesity situations [25].

As a strategy of change of body image for the practice of physical activity because it allows the elderly to live with peers who are going through similar changes, assisting in the process of acceptance of the body itself, rebuilding a more positive body image and self-esteem [26].

Some factors such as: positive perception of physical appearance and functional capacity, satisfaction about life and financial conditions, perception of happiness, acceptance/adjustment to age, relationship with the kids/family, desire to study and social contact, collaborate with the positive perception about self-image and self-esteem of seniors tickets in physical exercise programs [27].

\section{Conclusion}

On the above, it appears that the elderly present composition of body fat mass and high waist, hip ratio, according to the measure of proximity of Jaccard, thus most of the elderly are in opposition to a healthy lifestyle.

It is essential for the understanding of the characteristics and the transformations that the individuals with the advancement of age which reinforces the need for more effective actions in the control and/ or prevention of health-related factors in the elderly.

It's worth pointing out that these factors are subject of interventions and may interfere directly or indirectly on the quality of life of the elderly, since 
it improves the perception of body image of the elderly, being identified as a great ally in the physiological, psychological and social aspects.

\section{References}

1. Maués $C R$, Paschoal SMP, Jaluul O, França CC, Jacob Filho W. (2010, set-out.). Avaliação da qualidade de vida: comparação entre idosos jovens e muito idosos. São Paulo (SP): Revista Brasileira de Clínica Médica, 8(5), 405-410.

2. Ribeiro AS, Schoenfeldb BJ, Pinaa FLC, Souzaa MF, Nascimento MA, Santos L, Antunes M, Cyrino ES. Resistance training in older women: Comparison of single vs. multiple sets on muscle strength and body composition. Isokinetics and Exercise Science 23 (2015) 53-60.

3. Mazini Filho ML, Zanella AL, Aidar FJ, Silva AMS, Salgueiro RS, Matos DG. (2010, jan.-abr.). Atividade física e envelhecimento humano: a busca pelo envelhecimento saudável. Passo Fundo (RS): Revista Brasileira de Ciências do Envelhecimento Humano, 7(1), 97-106

4. Assumpção D, Domene SMA, Fisberg RM, Barros MBA. Qualidade da dieta e fatores associados entre idosos: estudo de base populacional em Campinas, São Paulo, Brasil. Cad. Saúde Pública, Rio de Janeiro, v. 30, n. 8, p. 1680-1694, ago. 2014. [acesso em: 05 abr. 2016]. Rio de Janeiro, 2014

5. D'Amico MM, SOUZA RK. Simultaneidade de Fatores de Risco Cardiovascular Controláveis: Estudo de Base Populacional. Rev Bras Cardiol. 2014. Vol. 27, n 5, pp. 318-326. 2014. [acesso em: 12 mar 2016].

6. Seino S, Shinkai S, Lijima K, Obuchi S, Fujiwara Y, Yoshida $H$, Kawai H, Nishi M, Murayama H, Taniguchi $Y$, Amano $H$, Takahashi R. Referend Values and Age Differences in Body Composition of Community- Dwelling Older Japanese Men and Women: A Pooled Analysis of Four Cohort Studies. Journal PlosOne. 2015 July [cited 2016 Apr. 11]; 10(7): e0131975.

7. Caluête MEE, Nóbrega AJS, Gouveia RA, Galvão FRO, Vaz LMM. Influência do estado nutricional na percepção da imagem corporal e autoestima de idosas. Rev. bras. Geriatr. Gerontol., Rio de Janeiro, v. 18, n. 2, p. 319-326, jun. 2015. [acesso em: 05 abr. 2016].

8. Santos MD, Rodrigues SSP, Oliveira BMPM, Almeida MDV Dietary availability in elderly Portuguese households. 2015. Public Health Nutrition: 18(3), 392-402. [Acesso em: 04 abr. 2016]. Public Health Nutrition. 2015.

9. Presidência da República. Casa Civil. Subchefia para Assuntos Jurídicos. Out. 2003.

10. Chumlea WC, Sun SS. Bioelectrical impedance analysis. In: Heymsfield SB, Lohman TG, Wang Z, Going SB, editors. Human body composition. 2nd ed. Champaign: Human Kinetics Books; 2005. p. $79-88$
11. Fürstenberg $A$, Davenport $A$. Comparison of multifrequency bioelectrical impedance analysis and dual-energy X-ray absorptiometry assessments in outpatient hemodialysis patients. Am J Kidney Dis. 2011;57(1):123-9

12. Toledo DR, Barela JA. Diferenças sensoriais e motoras entre jovens e idosos: contribuição somatossensorial no controle postural. Rev. Bras Fisioter [Internet] 2010 maio/jun.; 14(3):26775.

13. Brasil. Ministério da Saúde (BR). Resolução $n^{\circ}$ 466, de 12 de dezembro de 2012. Dispõe sobre Pesquisas com Seres Humanos. Diário Oficial da União. Brasília, 2012.

14. Zeinali F, Habibi N, Samadi M, Azam K, Djafarian K. Relation between Lifestyle and Socio-Demographic Factors and Body Composition among the Elderly. Global Journal of Health Science [Internet]. 2015 Dec [cited 2016 Apr 11]; doi:10.5539/ gjhs. v8n8p172.

15. Völgyi E, Tylavsky FA, Lyytikäinen A, Suominen $H$, Alén $M$, Cheng S. Assessing Body Composition with DXA and Bioimpedance: Effects of Obesity, Physical Activity, and Age. Obesity. 2008 January [ cited 2016 Apr 11].

16. Santos KT, Santos Júnior JCC, Rocha SV, Reis LA, Coqueiro RS, Fernandes $\mathrm{MH}$. Indicadores antropométricos de estado nutricional como preditores de capacidade em idosos. Rev. Bras Med Esporte [Internet]. 2014 June [cited 2016 Apr 11]; 20(3): 181-185.

17. Barbosa AR, Marchesan M, Guimarães AV, França VF, Marucci MFN, Coqueiro RS, Fernandes MH. Anthropometric indicators and their adequacy in older adults from two towns in distinct Brazilian regions. Medical Express (São Paulo, online) [Internet]. 2015 Dec. [cited 2016 Apr 11]; 2(6): M150605.

18. Silva NA, Pedraza DF, Menezes TN. Desempenho funcional e sua associação com variáveis antropométricas e de composição corporal em idosos. Ciênc. Saúde coletiva [Internet]. 2015 Dec. [cited 2016 Apr 11]; 20(12): 3723-3732.

19. Santos VR, Christofaro DGD, Gomes IC, Santos LL, Freitas Júnior IF. Predictive capacity of anthropometric indicators for abdominal fat in the oldest old. Rev. bras. Cineantropom. Desempenho Hum. [Internet]. 2013 Oct [cited 2016 Apr 18]; 15(5): 561-569.

20. Roriz AKC, Mello AL, Guimarães JF, Santos FC, Medeiros JMB, Sampaio LR. Avaliação por imagem da área de gordura visceral e suas correlações com alterações metabólicas. Arq. Bras. Cardiol. [Internet]. 2010 Dec. [cited 2016 Apr 11]; 95(6): 698-704.

21. Pereira ÉF, Teixeira CS, Borgatto AF, Daronco LSE. Relação entre diferentes indicadores antropométricos e a percepção da imagem corporal em idosas ativas. Ver Psiq. Clín. 2009 Dec. [cited 2016 Apr 11];36(2):54-9

22. Skopinski F, Resende TL, Schneider RH. Imagem corporal, humor e qualidade de vida. Rev. bras. Geriatr. Gerontol. [Internet]. 2015 Mar [acesso em: 11 de abr. 2016]; 18(1): 95-105. 
23. Queiroz RR, Rodrigues VD. Parâmetros antropométricos como discriminadores da obesidade, www.EFDesportes.com, Revista Digital. Buenos Aires - Año 17- N¹68- Mayo de 2012. [Acesso em: 16 abr. 2016].

24. Soares PG, Pádua V. (2014, março). Relação entre cinturaquadril e imagem corporal em mulheres de meia idade e idosas ativas fisicamente. Revista Kairós Gerontologia, 17(1), pp.283295. ISSN 1516-2567. ISSNe 2176-901X. São Paulo (SP), Brasil: FACHS/NEPE/PEPGG/PUC-SP. [acesso em: 16 de abr. 2016].

25. Provencher V, Bégin C, Gagnon-Girouard MP, Gagnon HC, Tremblay A, Boivin S, Lemieux S. Defined weight expectations in overweight women: anthropometrical, psychological and eating behavioral correlates. Int J. Obes. 2007;31(11):1731-38.

26. Seidel DC, Becker Junior B. Uma comparação sobre a autopercepção corporal de idosas praticantes de atividade física e sedentárias. Revista Digital Lecturas: Educación Física y Deportes, Buenos Aires, Ano 13, n.120, 2008.

27. Meurer ST, Benedetti TRB, Mazo GB. Aspectos da autoimagem e autoestima em idosos ativos. Motriz, Rio Claro, v. 15, n. 4, p. 788-796, 2009.

Publish in International Archives of Medicine

International Archives of Medicine is an open access journal publishing articles encompassing all aspects of medical science and clinical practice. IAM is considered a megajournal with independent sections on all areas of medicine. IAM is a really international journal with authors and board members from all around the world. The journal is widely indexed and classified Q1 in category Medicine. 